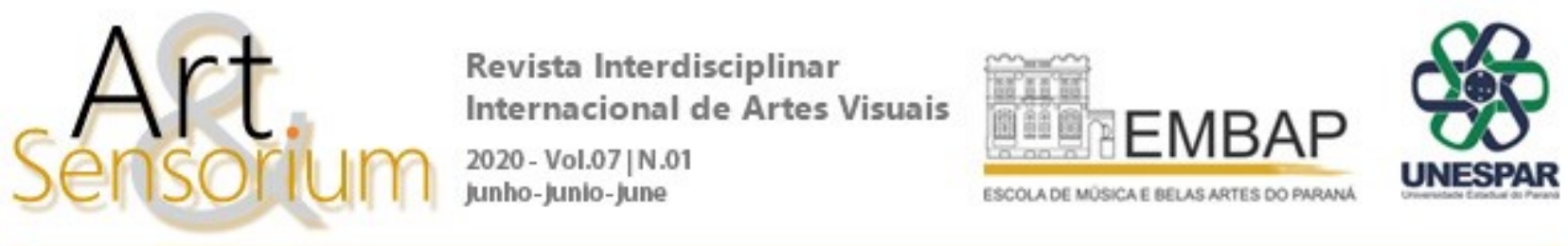

\title{
MINICURSO: MULHERES DO ATELIER 17: INSPIRAÇÕES E REFLEXÕES
}

\author{
DOI: https://doi.org/10.33871/23580437.2020.7.1.315-326
}

Rosane Maria Demeterco Bussmann ${ }^{1}$ Jane A. Marques ${ }^{2}$

\begin{abstract}
Resumo: Este ensaio apresenta como experiência pessoal, uma reflexão sobre o "Mini-cursoMulheres do Atelier 17," ministrado pela historiadora de arte, Christina Weyl, parte baseado nos eventos: a exposição "Atelier 17 e a gravuras nas Américas" e a conferência internacional "Atelier 17-a Gravura no Brasil e nos Estados Unidos: 1900 a 1950" que aconteceram no Museu de Arte Contemporânea da Universidade de São Paulo-MAC USP em 2019. O "Mini-curso" apresentou mulheres artistas que fizeram parte do Atelier 17-criado e fundado por Stanley Willian Hayter-na cidade de Nova Iorque entre 1940 e 1955. Em uma leitura particular, Sue Fuller destaca-se pela maneira criativa que incorporou no seu trabalho o uso de textura com tecido na composição e técnica de um dos seus trabalhos. Finalmente, a participação no estudo-As Mulheres do Atelier 17proporcionou reflexões e inspirações relacionadas a experiências com um coletivo de mulheres gravuristas nos Estados Unidos (2006-2009), que foram orientadas por Sylvie Covey. Ambos os casos utilizam processos inovadores de gravura e também demonstram a importância do trabalho coletivo e criativo para promover a troca de conhecimento entre os artistas e o mentor.
\end{abstract}

Palavras-chave: Atelier 17; Mulheres do Atelier 17; Gravura; Stanley William Hayter; Sue Fuller.

\section{MINI-COURSE: THE WOMEN OF ATELIER 17: INSPIRATIONS AND REFLECTIONS}

Abstract: This essay reflects a personal experience and view of the "Mini-course-The women of Atelier 17," ministered by the art historian, Christina Weyl, which was part of both the exhibition "Atelier 17 and the modern printmaking in the Americas" and the international conference entitled "Atelier 17-The Printmaking in Brazil and the United States of America: from 1900 to 1950" held at the Museum of Contemporary Art of University of São Paulo-MAC USP in 2019. The mini-course presented women artists that integrated Atelier 17-created and founded by Stanley Willian Hayter- in New York City between 1940 and 1955. In a particular narrative, Sue Fuller stands out for the creative way she incorporated the use of textile in the composition of one of her works. Finally, during her

\footnotetext{
${ }^{1}$ https://orcid.org/0000-0002-3108-3211-Universidade de São Paulo-São Paulo, SP, Brazil. PhD and CAPES scholarship student in the Interunits in the Aesthetics and Art History Graduate Program (PGEHA), at the University of São Paulo (USP), with research interest in Production and Circulation of Art. Was a member of the Deliberative Council of the Contemporary Art Museum (MAC USP) (2017-2018) as a student representative. Researcher in contemporary art history, contemporary global art, and São Paulo Art Biennials. Acts as Monitor in the Undergraduate Marketing Program at University of São Paulo. As a Graphic Designer and Visual Artist was awarded 1st place in printmaking (USA, 2007) and 2nd place in the "Bom Design Awards" (Brazil, 1996). E-mail: rosane.bussmann@usp.br

2 https://orcid.org/0000-0003-2382-9041-Universidade de São Paulo, SP, Brazil. Associate professor in the following Graduate Programs: Interunits in Aesthetics and Art History (acting sub-Coordinator), and Entrepreneurship Master, both at the University of São Paulo. A professor in the Undergraduate Marketing Program at the School of Arts, Sciences and Humanities, University of São Paulo. Researcher in the field of art production and distribution, focusing on the following themes: art market, creativity, creative industries, and creative economy. Experienced in reception research and interactive media and its impact on consumer behavior, especially on younger generations. E-mail: janemarq@usp.br
} 
participation in the study-The Women of Atelier 17-, under the guidance of Sylvie Covey, many reflections, and inspirations came to light that were related to experiences with a women's printmaking collective in the United States (2006-2009). Both cases used an innovative process in printmaking and also demonstrated the importance of collective and creative artwork to promote the exchange of knowledge between the artists and the mentor.

Key words: Atelier 17; Women of Atelier 17; Printmaking; Stanley William Hayter; Sue Fuller.

Resumen: Este ensayo presenta como una experiencia personal, una reflexión sobre el "Mini-CursoMujeres del Atelier 17", impartido por la historiadora de arte Christina Weyl, basado en los eventos: la exposición "Atelier 17 y grabados en las Américas" y la conferencia "Atelier 17-el grabado en Brasil y Estados Unidos: 1900 a 1950" que tuvo lugar en el Museo de Arte Contemporáneo de la Universidad de São Paulo- MAC USP en 2019. El "Mini-Curso" contó con mujeres artistas que hicieran parte del Atelier 17, creado y fundado por Stanley Willian Hayter, en la ciudad de Nueva York entre 1940 y 1955. En una lectura privada, Sue Fuller se destaca por la forma creativa en que incorporó el uso de la textura de la tela en su composición y la técnica de suyas obras. Finalmente, la participación en el estudio, de las Mujeres del Atelier 17, proporcionó ideas e inspiraciones relacionadas con las experiencias con un colectivo de grabado femenino en los Estados Unidos (2006-2009), que fueron dirigidas por Sylvie Covey. Ambos casos utilizan procesos innovadores de grabado y también demuestran la importancia del trabajo colectivo y creativo para promover el intercambio de conocimiento entre los artistas y el mentor.

Palabras llave: Atelier 17; Mujeres del taller 17; Grabado; Stanley William Hayter; Sue Fuller.

\section{Introduction}

This paper reflects a personal experience about the "Mini-course-The women of Atelier 17," which was ministered by the art historian, Christina Weyl ${ }^{3}$. The mini-course was a part of both an exhibition and an international conference, organized between the Museum of Contemporary Art of University of São Paulo-MAC USP (Brazil), where this event took place, the Terra Foundation for American Art (USA), and also the Brooklyn Museum (USA) and the Art Institute of Chicago (USA). Atelier 17 and the modern printmaking between the United States and Brazil in the 1950s was the theme and the focus point of the meeting and the exhibition entitled Atelier 17 e a gravura moderna nas Américas (Atelier 17 and modern printmaking in the Americas), curated by Carolina Rossettti de Toledo, Ana Gonçalves Magalhães, and Peter John Brownlee, and held from March $23^{\text {rd }}$ to June $2^{\text {nd }}$ 2019. The mini-course, The women of Atelier 17, was conducted between April $15^{\text {th }}$ and $18^{\text {th }}, 2019$ (MAC, 2019). The exhibition held at the $3^{\text {rd }}$ floor of the Museum of Contemporary Art of the University of São Paulo presented 53 printmaking art works made between 1910 and 1960 (TOLEDO; MAGALHÃES; BROWNLEE, 2019). There, we had the opportunity to contemplate the engraving ${ }^{4}$ works of "the creator and founder of Atelier 17," Stanley Willian Hayter" ${ }^{5}$ along with the

\footnotetext{
${ }^{3}$ Christina Weyl - Art historian, independent scholar \& curator. BA from Georgetown University, with MA and PhD in Art History from Rutgers University. Available at: http://christinaweyl.com._Access: 30 Nov. 2019.

${ }^{4}$ Engraving - Intaglio technique in which the image is produced by cutting a metal plate directly using a sharp engraving tool. The incised lines are inked and printed with the application of heavy pressure (SAFF; SACILOTTO, 1978, p. 427).

5 Stanley William Hayter - (London, England, 1901 - Paris, France, 1988). During the late 1920s, Stanley Willian Hayter, an English printmaker working in Paris, established an experimental graphics workshop called Atelier 17. [...] In 1940, Atelier 17 moved to New York and was housed at the New School for Social Research (SAFF; SACILOTTO, 1978, p. 117).
} 
works of some of his followers from Brazil and United States, among them: Minna Citron ${ }^{6}$, Jackson Pollock $^{7}$, Sue Fuller ${ }^{8}$, Geraldo de Barros ${ }^{9}$, and Lívio Abramo ${ }^{10 "}$ (MAGALHÃES, 2019, p. 10).

But who was Stanley Willian Hayter?

Hayter was widely known as an experimental printmaker and teacher, a quality that infused his leadership of Atelier 17 in both Paris and New York. He was fascinated by the expressiveness of copper engraving, a technique that had fallen out of fashion due to its exacting and time-consuming nature. On the smooth, metallic surface of copper, lines could be drawn directly onto the plate with a freedom that aligned with Hayter's artistic interest in automatic drawing and amorphous, organic shapes, or biomorphism. (MAC, 2019)

Watching Hayter's technique in "New Ways of Gravure," the documentary about Atelier 17 in Paris (MAC, 2019) written and produced by his son, Julian Hayter (HAYTER, n. d.), we were able to see the artist himself, working hands on first on his drawing and after, on his copper plate. Hayter works so freely, rhythmically, tracing very expressive, and strong lines with his burin, such that we can be sure of the importance of his work both technically and aesthetically. He also develops a technique with different fabric textures to compose his art work. It is important to make it clear that this engraving technique Hayter had employed is very difficult to master. It is necessary to have a high training level and knowledge of the techniques, to control the engraving tools, even to be able to print the image. Hayter was an inspiration for those artists who had the opportunity to frequent the Atelier 17.

Hayter believed that "the constant pulling off proofs for each stage of a print" would give to the artist the opportunity to "learn the effects" of each process and, consequently, the ability to make decisions as well as, with time, the experience and expertise required by each technique that has been developed (TOLEDO; MAGALHÃES; BROWNLEE, 2019, p. 230).

In the piece "Tarantelle" (Figure 1), Hayter expressed with perfection how he has mastered technique-soft ground etching ${ }^{11}$ and burin on paper, in this case-along with composition, movement, contrast, and abstraction. However, Hayter considered materials and tools as "instruments of discovery" (SHAFER, 2019, p. 72). "While his books and technical innovations have insured his reputation as a master of his craft, for Hayter, the mechanical piece was inseparable from the development of ideas. One led to the other in a Möbius strip of cause and effect" (SHAFER, 2019, p. 72).

Tarantelle is a soft ground technique. [...] it was a common practice at Atelier 17 to incorporate a variety of textiles (silk, gaze, net, and even wood) to imprint different

\footnotetext{
${ }^{6}$ Minna Citron (Newark, NJ, USA, 1896 - New York, NY, USA - 1991). Her work was exhibited in the I and II São Paulo Biennials (1951 and 1953). Additionally, she received a solo exhibition of her painting and prints at the Museum of Modern Art of São Paulo in 1952. Such level of exposure was rare for Atelier 17 artists in Brazil (TOLEDO; MAGALHÃES; BROWNLEE, 2019, p. 212).

7 Jackson Pollock (Cody, WY, USA, 1912 - East Hampton, NY, USA - 1956).

${ }^{8}$ Sue Fuller (Pittsburg, PA, USA, 1914 - South Hampton, NY, USA - 2006).

${ }^{9}$ Geraldo de Barros (Chavantes, São Paulo, 1923 - São Paulo, São Paulo, 1998) - Brazilian artist best known for his work as a painter associated with Concrete art, as a furniture designer, and for his photographic works. Less widely commented is his production of drawings, monotypes and engravings made during a period of formation between 1946 and 1951 (ESPADA, 2019, p. 148).

${ }^{10}$ Lívio Abramo (Araraquara, São Paulo, 1903 - Asunción, Paraguay 1992) - Printmaker, illustrator, designer. In Paris he attended Atelier 17, perfecting himself in metal engraving with Stanley William Hayter (1901-1988). He is the founder of the Institute of Historical and Artistic Heritage of Paraguay (ENCICLOPÉDIA ITAÚ CULTURAL, our translation).

11 Soft ground - see ground (SAFF; SACILOTTO, 1978). Ground - In etching and aquatint, an acid-resistant substance used to protect non-image areas of the plate from the action of the acid. Hard ground contains asphaltum, beewax, and rosin; soft grounds contain the same ingredients plus tallow (SAFF; SACILOTTO, 1978, p. 427).
} 
patterns. The fabrics were pushed into resin, creating volume. The plate was then dressed with varnish in certain sections and only specific portions were exposed to acid, creating the effect of an overlapping shadow. In Tarantelle, the combination of these two techniques create a couple of human-like figures (one made of line and the other of volume) that are entangled in a spirited dance (TOLEDO; MAGALHÃES; BROWNLEE, 2019, p. 230).

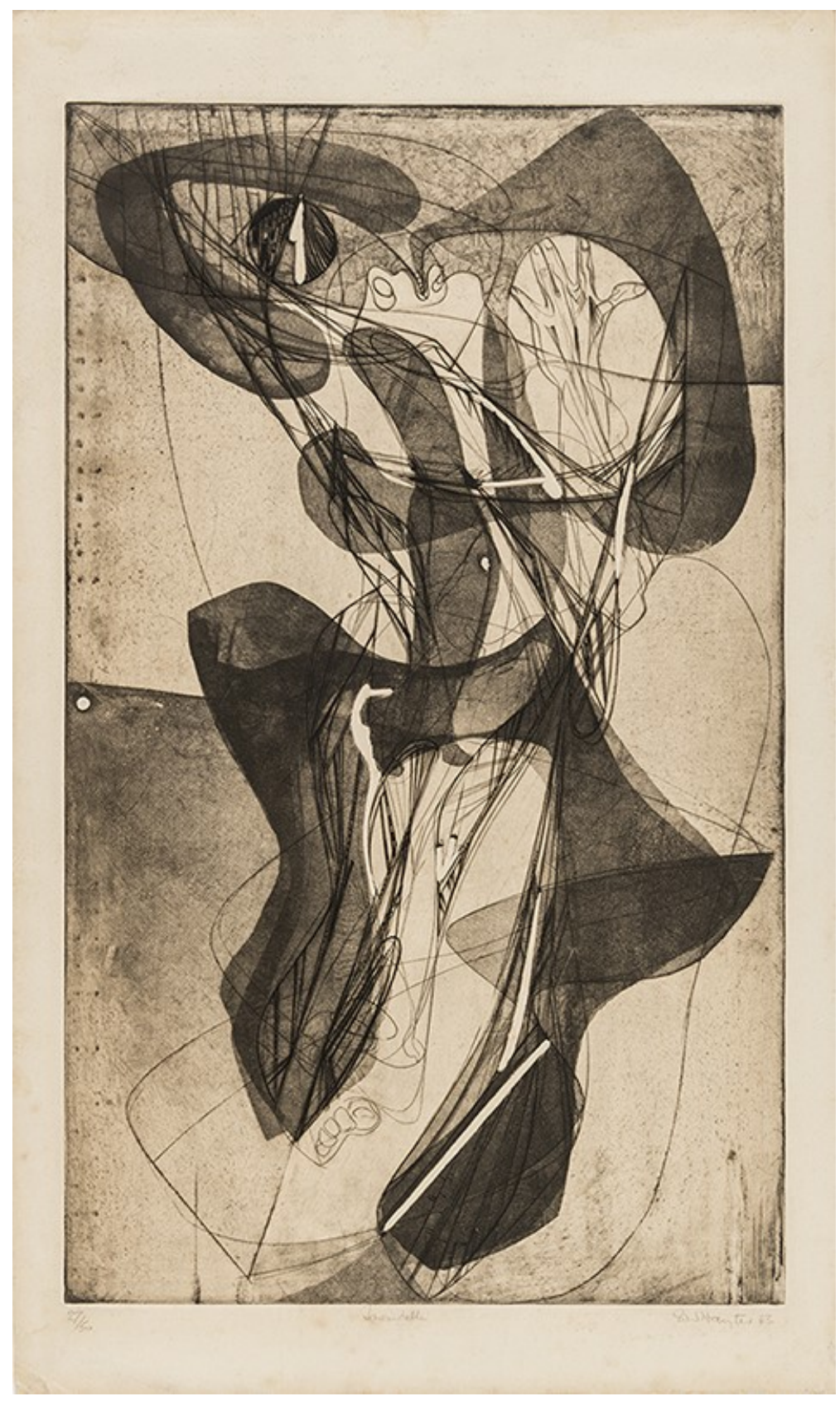

Figure 1. S. W. Hayter, "Tarentelle", 1943. Technique-color soft ground etching and burin on paper. Print Edition27/50. Dimensions- 55,2 x 33cm. Donation by MAM SP. Provenance-Acquired by Nelson Rockefeller through The Buchloz Gallery (MAC, 2019, p. 228). MAC USP Collection. MAC USP Archive. Photo-Ding Musa. 


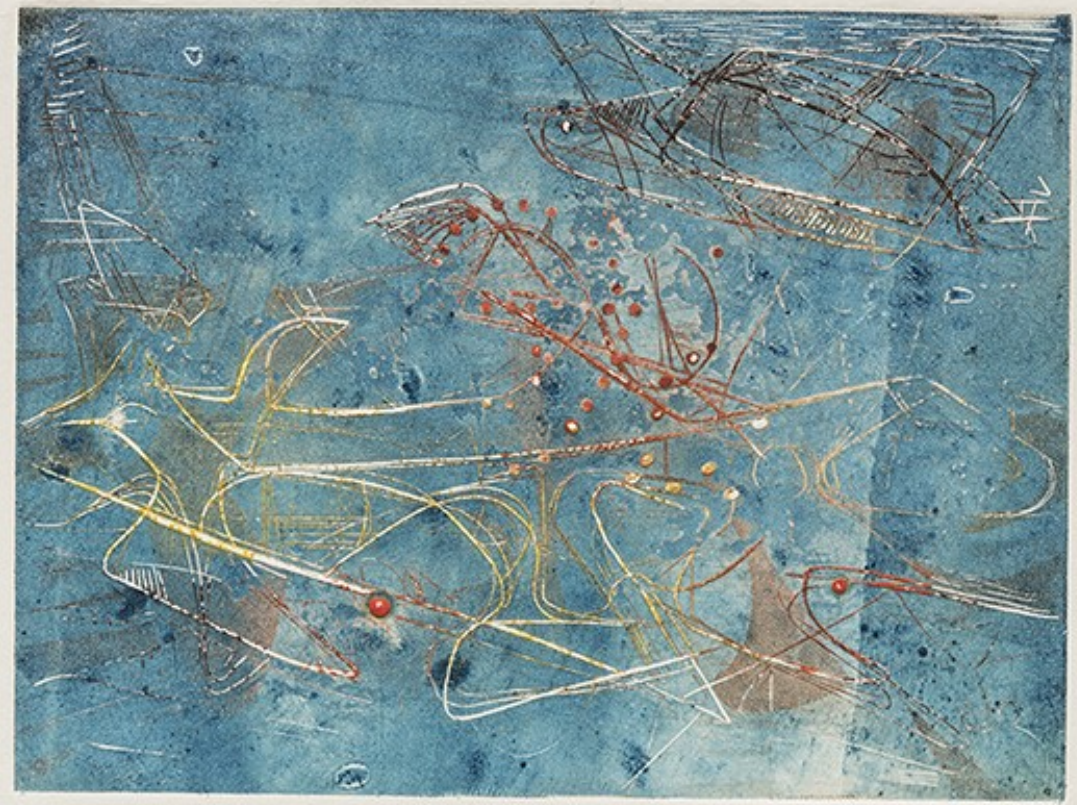

Figure 2. S. W. Hayter, "Composition,” 1952. Technique-monotype with burin on paper. Dimensions-20,8 x 23,5 cm (11 x 14,8 cm). Donation by Associação Pinacoteca Arte e Cultura. MAC USP Collection. MAC USP Archive. PhotoDing Musa. 


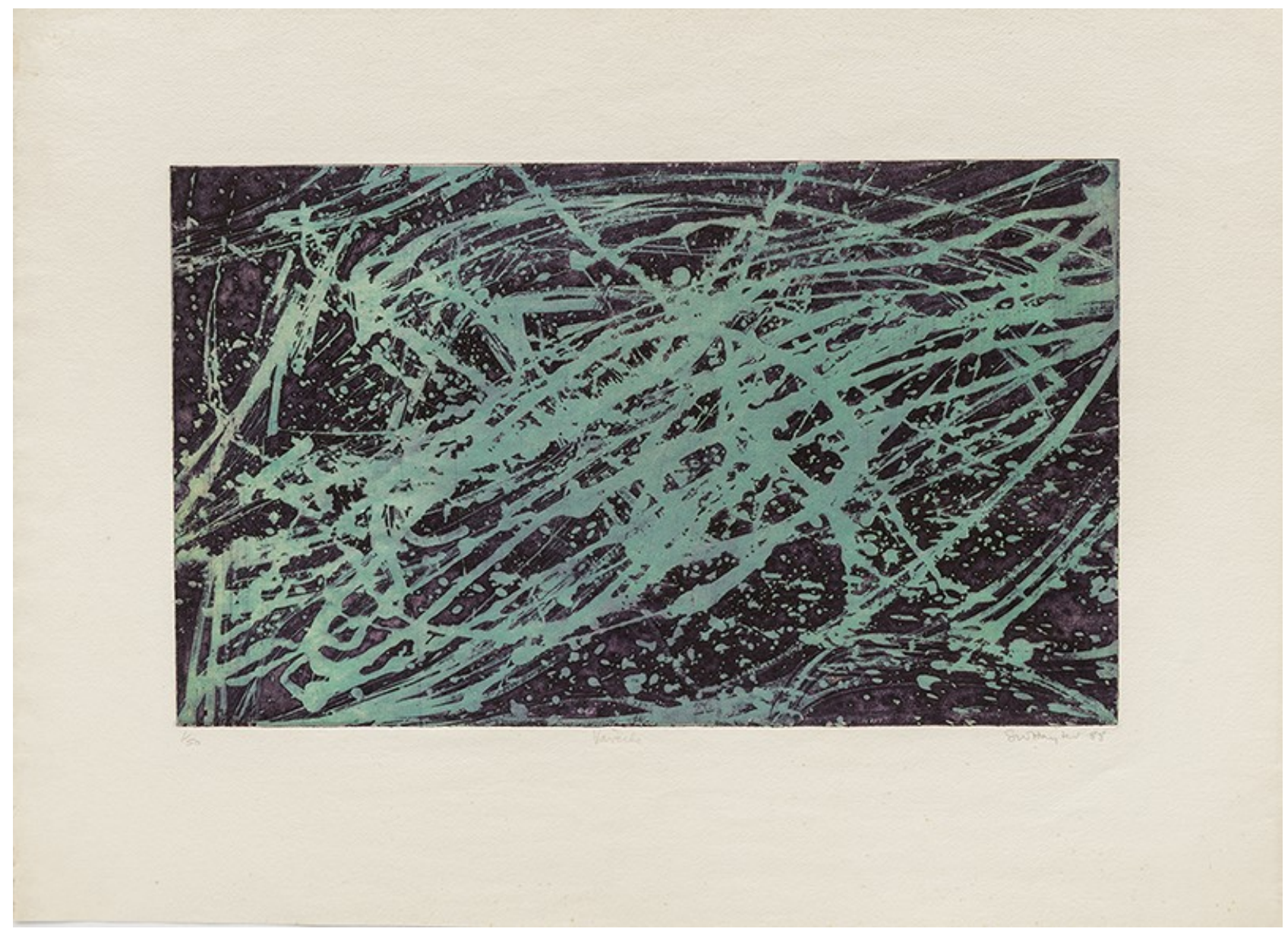

Figure 3. S. W. Hayter, "Varèche", 1958. Technique-color soft ground etching and burin on paper. Print Edition-1/50. Dimensions-48,9 x 67,5 cm (29,8 x 49,8 cm). Donation by Francisco Matarazzo Sobrinho. MAC USP Collection. MAC USP Archive. Photo-Ding Musa.

And what was the importance of the Atelier 17? According to Toledo ${ }^{12}$ (2019, p. 30):

There is no other collection of modern American prints in Brazil as significant as the one currently housed at the Museum of Contemporary Art of the University of São Paulo. This graphic nucleus is formed of more than 40 works, mostly of artists who worked or collaborated to some extent, with Atelier 17. Atelier 17 was an experimental center for innovative printmaking. Originally inaugurated in 1927 in Paris, the atelier was reinstalled in New York in 1940 because of increased hostilities during World War II.

During the time the Atelier 17 was on exhibit in Paris, some important avant-garde artists including Marc Chagall, Joan Miró, André Masson and Pablo Picasso frequented Hayter's studio (TOLEDO, 2019, apud KAINER, 1992). Already, when Atelier 17 settled down in New York, some expressionist abstract artists such as Jackson Pollock, Mark Rothko, Adolph Gottlieb and Louise Nevelson (TOLEDO, 2019, apud WYE, 2014) "worked in the studio at different periods and capabilities," says

\footnotetext{
12 Carolina Rossetti de Toledo - She holds a Bachelor of Arts degree in Journalism at USP's School of Communications and Arts, a Master's Degree in Aesthetics and Art History from the University of São Paulo, and Masters in Liberal Arts in the Field of Museum Studies, Harvard University Extension School. She is currently the Institutional Relations supervisor at the São Paulo Art Museum Assis Chateaubriand (MASP). (Text informed by the author, our translation). Available at: http://buscatextual.cnpq.br/buscatextual/visualizacv.do?id=K4206596T6. Access: 20 May. 2019.
} 
Toledo (2019, p. 30). According to Christina Weyl (at the mini-course-The Women at Atelier 17, 2019), Hayter maintained the Atelier 17 in New York until 1955. Some of the characteristics of Atelier 17 were: 1) the study was always making ways to print in colors; 2) it was a very fertile studio in terms of creativity and the focus would change at any giving time; 3 ) it fostered a collaborative environment such that everybody was learning with and from each other (WEYL, 2019, Mini-course: the Women at Atelier 17).

Now, after a very brief discussion of who Stanley Willian Hayter was and the importance of the Atelier 17, it is time to refer to some of the women that went through Atelier 17. As Christina Weyl brought to us at the "Mini-course: The women of Atelier 17," some of these women included Louise Nevelson (1899-1988), Louise Bourgeois (1924-2006), Minna Citron (1896-1991), Worden Day (1916-1986), Dorothy Dehner (1901-1994), Sue Fuller (1914-2006), Alice Trumbull Mason (19041971), and Anne Ryan (1889-1954) (WEYL, 2019).

Minna Citron print "Squid Under Pier" (1948) (Figure 4) demonstrates how she was influenced by her mentor Hayter. The movements, the rhythm, the different thicknesses of the lines, and the layers are all particular to some Hayter's prints. "According to Citron, the artist's movements are as important to the work as the resulting visual register." (TOLEDO; MAGALHÃES; BROWNLEE, 2019, p. 214).

"The Museum of Contemporary Art of University of São Paulo (MAC USP), has four of Citron's works," as she is one of "the Atelier 17 artists that received great notice in Brazil." (TOLEDO; MAGALHÃES; BROWNLEE, 2019, p. 214). 


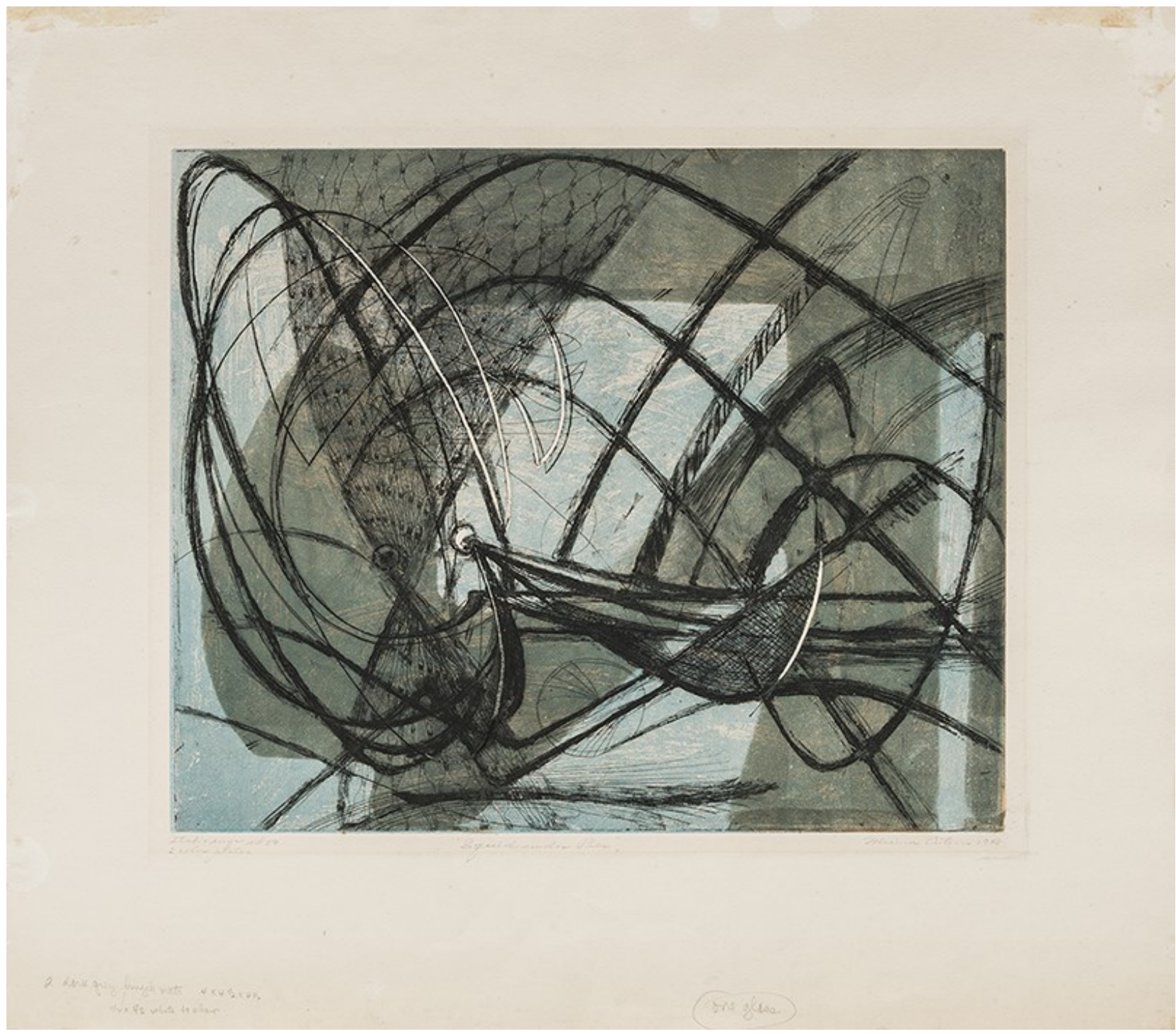

Figure 4. Minna Citron, "Squid Under Pier", 1948. Technique-color engraving on paper. Dimensions-56,5 x 65,1 cm (37,3 x 45,7 cm). Donation by Francisco Matarazzo Sobrinho. Provenance- Donation by Nelson Rockfeller, 1951. Acquired through The Weyhe Gallery, New York. (MAC, 2019, p. 212-213). MAC USP Collection. MAC USP Archive. Photo-Ding Musa.

From all of these women artists that frequented Atelier 17, one caught our eyes because of her amazing art pieces. The name of this artist is Sue Fuller ${ }^{13}$.

"Sue Fuller would become one of the better-know women artists associated with Atelier 17. She was one of the only female artists represented with multiples works at the iconic Hayter and Studio 17: New Ways of Gravure exhibition at MoMA (1944).” (TOLEDO; MAGALHÃES; BROWNLEE, 2019, p. 226).

\footnotetext{
13 See the oral interview with Sue Fuller, 1975 Apr. 24 - May 8. Available at: http://www.aaa.si.edu/collections/interviews/oral-history-interview-sue-fuller-13068\#transcript (ARCHIVES OF AMERICAN ART, SMITHSONIAN INSTITUTION, apud TOLEDO; MAGALHÃES; BROWNLEE, 2019, p. 226).
} 


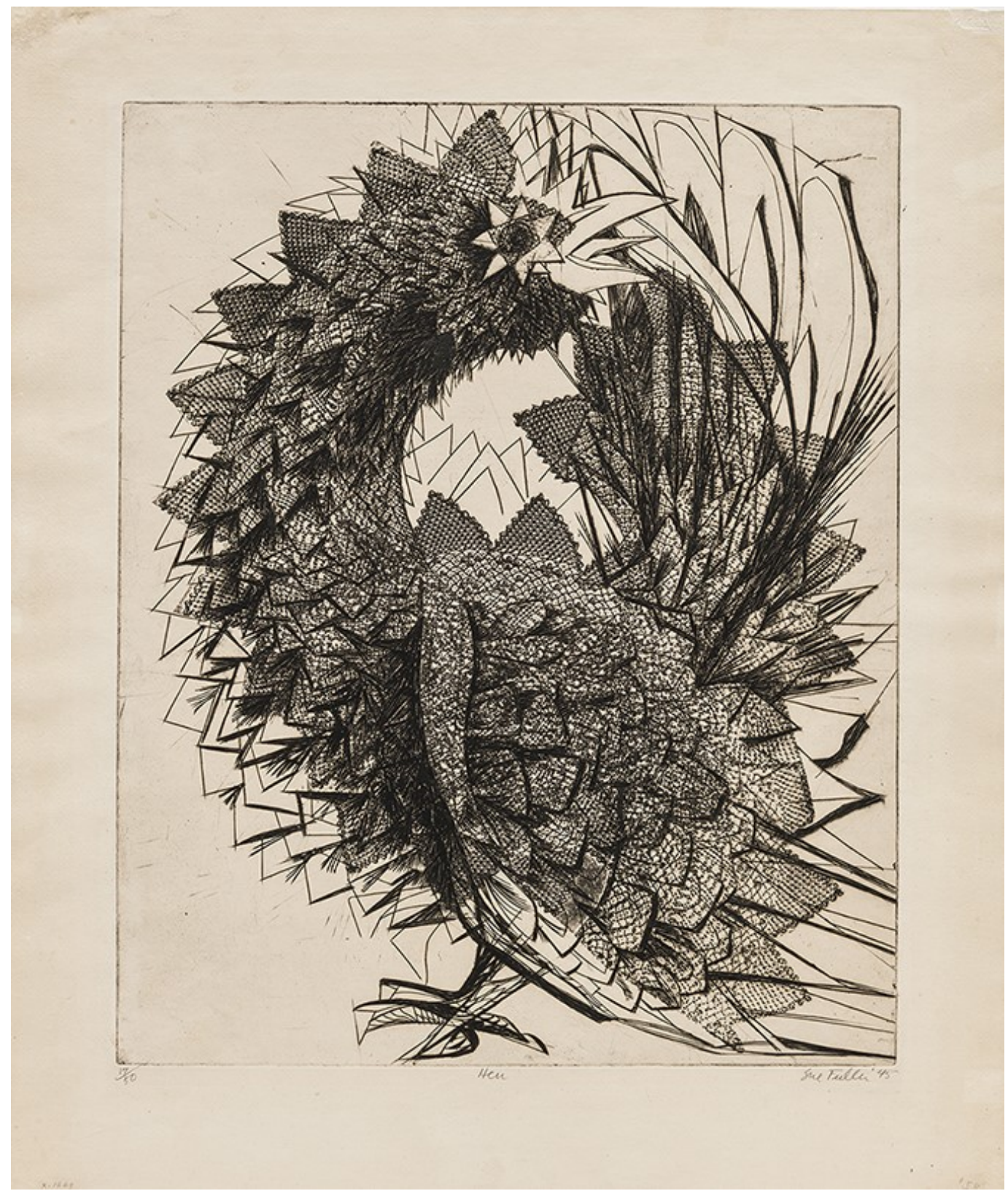

Figure 5. Sue Fuller, "Hen”, 1945. Technique-soft ground etching on paper Print edition-17/50. Dimensions-46,4 x $39 \mathrm{~cm}(37,4$ x 30,3 cm]. Donation by MAM SP. Provenance-Acquired by Nelson Rockfeller from Bertha Schaefer Gallery, in New York. (MAC, 2019, p. 228) (MAC USP Collection). Photo-Ding Musa.

Sue Fuller is credited with an exquisite piece of artwork termed "Hen" (Figure 5), described as "one of her most famous prints" (MAC, 2019). This piece of work was at the exhibition ${ }^{14}$, which we had the privilege to closely contemplate at. What called our attention to this piece was it being apparently the overall product of a laudable combination of technique, creativity, sensibility and aesthetics. Fuller used for this print (Hen) two pieces of lace forming "the collar of her mother's dress" as the body of the image, combined with some strong, and detailed traits of etched lines that form the feathers, the beak, and the head of the bird. The effect of this combination is an imagines idea that is very significant and symbolic if it is considered that it was made after the death of her mother. Acknowledging this fact, it is possible to perceive her strong connection with her mother that she demonstrates in this print. Instead, of simply saving the collars of the dress of her deceased mother, she transformed it into an art piece, revealing how she transcends her emotions and sensibility through

\footnotetext{
14 Atelier 17 e a gravura moderna nas Américas [Atelier 17 and modern engraving in the Americas], Contemporary Art
} Museum of the University of São Paulo, 2019. 
the art world (MAC, 2019). It is possible to understand even more the meaning of the piece "Hen" (1945) when one discovers that: "Sue Fuller's mother was skilled in crocheting and knitting and their home was always filled with baskets of thread and yarn. Fuller's work explores these domestic crafts through the fine art media of printmaking and sculpture" (SMITHSONIAN AMERICAN ART MUSEUM-SAAM, n. d). Also, an important aspect that links Fuller's artwork with Atelier 17 is the incorporation of textiles in the process of printmaking, as mentioned before, which is a characteristic aspect in other artists works at Atelier 17, as can be noticed in some of Hayter's prints.

Hen was made while Fuller was working as an assistant to Hayter. This print evidences her practice of incorporating textiles into the process of printmaking, a technique widely used by other Atelier 17 artists, most notoriously Louise Bourgeois, and Hayter himself. "Instead of crosshatching, you could use a fabric and so it became a collage technique in metal plate," described Sue Fuller in an interview (MAC, 2019).

\section{Final Considerations}

In conclusion, as a part of this mini-course taught by Christine Weyl (2019), many reflections and inspirations came to light regarding our experience as visual artists who had worked with printmaking some time ago. Awakened by the desire to work with prints again. Having the opportunity to live in New Jersey, USA for eleven years, and being part of a printmaking group in New Milford, New Jersey, at Art Center of Northern New Jersey ${ }^{15}$ from 2006 to 2009, it was possible to feel a deep connection with all these women artists we were privileged to know through Weyl's teachings about Atelier 17. Hayter influenced and inspired a group or artists who used to learn experimental processes and engage in knowledge exchange with each other. In the other hand, we had the opportunity to be present in some artists' meetings (2006-2009). In particular, we were able to observe or attend a weekly meeting of a group of women who banded to learn, to produce, and also to share ideas and knowledge about our printmaking artworks. Their meetings were guided by Sylvie Covey ${ }^{16}$, teacher and talented French artist who have inspired us with her dedication, knowledge, and vast experience with many different kinds of printmaking techniques such as, polyester pronto plate lithography ${ }^{17}$,

\footnotetext{
15 Art Center of Northern New Jersey. Available at: http://artcenter-nnj.org. Access: 18 May 2019.

16 Sylvie Covey is a master printer and a printmaking professor at the Fashion Institute of Technology and a Printmaking Instructor at the Art Students league of New York and the The Art Center of Northern New Jersey. She owns a printmaking studio in Times Square, Manhattan, where she pursues her work in all media, and she currently concentrates on combining digital and photographic techniques with printmaking. She also currently teaches a new course in Photoshop software, "Photoshop for Artists", which she developed herself. Her work has been exhibited all over the world. Available at: www.sylviecovey.com and https://www.theartstudentsleague.org/instructor/sylvie-covey/._Access: 30 Nov. 2019.

17 Polyester Pronto Plate Lithography - Polyester lithography were first developed in India as a means for less-expensive off-set printing (COVEY, 2012, p. 266). This technique demonstrates how to generate pronto plates to print a full-color image from a separation of colors, resulting in four transparencies and plates in cyan, magenta, yellow and black. Printing and registering the four plates will render the full color range of the image (COVEY, 2012, p. 267).
} 
tiling technique for CMYK (Cyan, Magenta, Yellow and Black) color separations ${ }^{18}$, mixed-media painting and printmaking ${ }^{19}$, solvent transfers ${ }^{20}$, and others.

Both experiences, the mini-course about Atelier 17 and the involvement with the process of hands on printmaking, elements of which include, creativity, the theoretical, and practical understanding of a subject, techniques, and tools, combined to inspire and reflect upon the importance of the collective and creative artwork that promotes the exchange of knowledge, experiences, and ideas between the artists and the mentor; the freedom to experiment with innovative techniques; the persistence and patience to learn, to understand and to manage new printmaking processes; and the conscious realization that it takes time to master a print technique, as articulated in Hayter's comparison of "printmaking [with] a game of chess. An experienced player would foresee results many steps ahead, while a novice would only be able to perceive the immediate consequence of a movement" (HAYTER, 1949 apud TOLEDO; MAGALHÃES; BROWNLEE, 2019, p.230). As the old saying goes, the more you know, the more you realize you don't know.

\section{References}

ARCHIVES OF AMERICAN ART, SMITHSONIAN INSTITUTION. Oral history interview with Sue Fuller, 1975 April 24-May 8. Available at: https://www.aaa.si.edu/collections/interviews/oralhistory-interview-sue-fuller-13068\#transcript. Access: 3 Dec. 2019.

COVEY, Sylvie. Photoshop for artists: a complete guide for fine artists, photographers, and printmakers. New York: Watson-Guptill Publications, 2012.

ENCICLOPÉDIA ITAÚ CULTURAL. Livio Abramo. Available at: http://enciclopedia.itaucultural.org.br/pessoa9132/livio-abramo. Access: 2 Dec. 2019.

ESPADA, H. The collection of prints by Geraldo de Barros at MAC USP and some hypotheses about his passing through Atelier 17. In: MAC. Atelier 17 e a gravura moderna nas Américas [Atelier 17 and modern engraving in the Americas]. Catálogo de exposição [Exhibition Catalog]. [São Paulo]: MAC, [2019]. p. 148.

GUGGENHEIN. Jackson Pollock. Available at: https://www.guggenheim.org/artwork/artist/jackson-pollock. Access: 2 Dec. 2019.

HAYTER, J. (produced and written). New Ways of Gravure. Documentary written and produced by Julian Hayter, sun of Stanley Willian Hayter, about atelier 17 in Paris, sd. Available at: https://www.youtube.com/watch?v=wUIM9ZiMqzw. Access: 19 May. 2019.

HAYTER, S. W. New ways of gravure. New York: Pantheon, 1949.

. New ways of gravure. New York: Watson-Guptill Publications, 1981.

KAINER, J. Stanley Willian Hayter: an introduction. In: Black, Peter, et. al. The prints of Stanley Willian Hayter: a complete catalogue, 1992.

\footnotetext{
18 Tiling Technique for CMYK Color Separations - Tiling is often necessary when creating large prints because the pronto plates must fit in a laser printer. Large-sized printers are not always affordable for most artists. Tilling the image in sectors allows printing in larger formats (COVEY, 2012, p. 270).

${ }^{19}$ Mixed-media Painting and Printmaking - Mixing techniques is a wonderful way to create rich and sophisticated prints. Today's technology permits photographic imagery to be combined with hand-created works to produce mixed-media print. Many artists have found ways to integrate digital imaging with traditional print media (COVEY, 2012, p. 280).

20 Solvent Transfers - The principle of solvent transfers is that the solvent dissolves the toner from the laser print or the ink from the inkjet printer and transfers on the substrate surface when pressure is applied. The use of a printing press is usually necessary but in some cases a handheld brayer roll will work fine (COVEY, 2012, p. 296).
} 
MAGALHÃES, A. G. Atelier 17 in the Tropic of Capricorn. In: MAC. Atelier 17 e a gravura moderna nas Américas [Atelier 17 and modern engraving in the Americas]. Catálogo de exposição [Exhibition Catalog]. [São Paulo]: MAC, [2019].

MAC. MUSEU DE ARTE CONTEMPORÂNEA DA UNIVERSIDADE DE SÃO PAULO. Atelier 17 e a gravura moderna nas Américas [Atelier 17 and modern engraving in the Americas]. Available at: http://www.mac.usp.br/mac/expos/2019/atelier17/curadores.html\#topo. Access: 30 Nov. 2019.

SACCHETTIN, P. Lívio Abramo: learning and teaching. In: MAC. Atelier 17 e a gravura moderna nas Américas [Atelier 17 and modern engraving in the Americas]. Catálogo de exposição [Exhibition Catalog]. [São Paulo]: MAC, [2019].

SAFF, D.; SACILOTTO, D. Printmaking: history and process. United States of America: Thompson Learning, Inc., 1978.

SHAFER, Ann. Atelier 17 and its founder, Stanley Willian Hayter. In: MAC. Atelier 17 e a gravura moderna nas Américas [Atelier 17 and modern engraving in the Americas]. Catálogo de exposição [Exhibition Catalog]. [São Paulo]: MAC, [2019].

SAAM-SMITHSONIAN AMERICAN ART MUSEUM. Sue Fuller. Available at: https://americanart.si.edu/artist/sue-fuller-1701. Access: 3 Dec. 2019.

TOLEDO, C. R. de. As doações Nelson Rockefeller no acervo do Museu de Arte Contemporânea da Universidade de São Paulo. MA (thesis presented in 2015. MAC USP. Available at: http://www.teses.usp.br/teses/disponiveis/93/93131/tde-29012016-105805/pt-br.php. Access: 18 May 2019.

TOLEDO, C. R. de; MAGALHÃES, A. G.; BROWNLEE, J. (Org.). Atelier 17 e a gravura moderna nas Américas [Atelier 17 and modern engraving in the Americas]. Catálogo da exposição [Exhibition Catalog]. São Paulo: MAC, 2019. 308 p.

WEYL, Christina. Christina Weyl. Available at: http://christinaweyl.com. Access: 30 Nov. 2019. . Mini-course: The Women at Atelier 17. MAC, 15 Apr. to 18 Apr. 2019. 